\title{
Dentin surface and hybrid layer morphological analysis after use of a copaiba oil- based dentin biomodifier
}

\section{Análise morfológica da superfície dentinária e da camada híbrida após o uso de um biomodificador dentinário à base de óleo de copaíba}

\author{
Luanny Gomes Moura ${ }^{1 *}$, Gerson Paiva Neto ${ }^{1}$, Cristiane Nagai Coelho de Bari ${ }^{1}$, Geisy Rebouças \\ Lima $^{2}$, Carina Toda ${ }^{1}$, Simone Assayag Hanan ${ }^{1}$, Nikeila Chacon de Oliveira Conde ${ }^{1}$, Maria \\ Fulgência Costa Lima Bandeira ${ }^{1}$
}

\begin{abstract}
This study evaluated dentin surface and hybrid layer's morphology, using copaíba (CO) emulsion as dentin biomodifier before traditional and self-etching adhesive, by environmental scanning electron microscopy (ESEM). Ninety-six third sound molars were divided into 16 groups, according to the dentin substrate, tested substances, and the adhesive system used. The conditioned dentin surface treated with clorexidina (CHX) 2\% showed phosphate salts on two dentin substrates as well as the sound conditioned or not surface treated with calcium hydroxide solution (CHS), where the mineral precipitate deposition obstructs the tubules lumen. A significant difference $(\mathrm{p}<0.0001)$ in dentin surface morphology was observed at the CHS group on conditioned and not conditioned sound dentin. The $\mathrm{CO}$ emulsion produced a regular and homogenous hybrid layer with many resin tags on both dentin surfaces, irrespective of the adhesive system used, with better performance than CHS and CHX 2\% ( $p=0.0007)$ on caries-affected dentin at the selfetching group. $\mathrm{CO}$ emulsion showed no morphological changes on sound and caries-affected dentin and presented a regular hybrid layer, regardless of the adhesive system used.
\end{abstract}

Keywords: Copaiba oleoresin; Emulsions; Dentin-bonding agents; Phytotherapy.

\section{RESUMO}

Este estudo avaliou a morfologia da superfície dentinária e da camada híbrida, utilizando a emulsão de copaíba (CO) como biomodificador dentinário antes do uso de adesivo universal e autocondicionante, por microscopia eletrônica de varredura ambiental (MEV). Noventa e seis terceiros molares hígidos foram divididos em 16 grupos, de acordo com o substrato dentinário, as substâncias testadas e o sistema adesivo utilizado. A superfície dentinária condicionada tratada com clorexidina (CLX) $2 \%$ apresentou sais de fosfato nos substratos dentinários, bem como a superfície condicionada ou não tratada com solução de hidróxido de cálcio (CHS), onde a deposição de precipitado mineral obstruiu a luz dos túbulos. Uma diferença significativa ( $\mathrm{p}<0,0001$ ) na morfologia da superfície dentinária foi observada no grupo CHS na dentina hígida condicionada ou não. A emulsão de CO produziu uma camada híbrida regular e homogênea em ambas as superfícies dentinárias, superior à CHS e CLX 2\% (p=0,0007) em dentina afetada e no grupo

\footnotetext{
${ }^{1}$ School of Dentistry, Amazonas Federal University, Manaus, AM, Brazil.

${ }^{2}$ School of Pharmaceutical Sciences, Amazonas Federal University, Manaus, AM, Brazil.

*E-mail: luanny_moura@hotmail.com
} 
do adesivo autocondicionante. A emulsão de CO não apresentou alterações morfológicas em ambos os substratos dentinários e mostrou uma camada híbrida regular, independentemente do adesivo utilizado.

Palavras-chave: Óleo-resina de Copaíba; Emulsões; Adesivos dentinários; Fitoterapia.

\section{INTRODUÇÃO}

Adhesion of restorative material to dentin occurs when adhesive infiltrates the demineralized dentin by acid etching, encapsulating the exposed collagen fibers and protecting the proteolytic's adhesive interface and hydrolytic degradation. The demineralized dentin infiltrated by adhesive is called a hybrid layer (NAKABAYASHI, 1992).

Current adhesive systems interact with the enamel/dentin substrate using two different strategies, i.e., either removing the smear layer (etch-and-rinse technique) or maintaining it as the substrate for the bonding (self-etch technique) (OZER; BLATZ, 2013) .

Since adhesion requires intimate contact between adhesive and dentin surface, a failure in operative steps can compromise hybrid layer quality and affect adhesion and bond strength of restorative material to dentin reducing the longevity of the restoration (SKUPIEN et al., 2010). The treatment of the dentin surface before the restorative procedure also influences the hybrid layer formation. A dentin cleaning substance, highlighting chlorhexidine ( $\mathrm{CHX}$ ) as the most commonly used, must has an inhibitory effect on proteolytic enzyme (Metalloproteinases -MMPs) action and the hybrid layer's collagen matrix degradation (BRESCHI et al., 2010; LAFUENTE, 2012; SAFFARPOUR et al., 2016).

Using medicinal plants for curative treatments of diseases has been undertaken to produce herbal products as an alternative to traditional drugs. The copaiba (CO) oleoresin has antiseptic, anti-inflammatory, antibacterial, and antifungal properties with promising results in dentistry (BANDEIRA et al., 2018; GARRIDO et al., 2010; ARAÚJO et al., 2020). Concerning the biological properties of CO oleoresin (BANDEIRA et al., 2018; BANDEIRA et al., 2020; PIERI et al., 2012), a CO oil emulsion was formulated to be used before adhesive application with potential action to inhibit MMP-2 and MMP-9, thereby improving dentin adhesion of restorative materials to a dental structure. 
This study sought to evaluate the morphology of dentin surface and the hybrid layer using $\mathrm{CO}$ emulsion as a dentin biomodifying agent on sound and caries-affected dentin. The null hypotheses tested were: a) dentin surface morphology would not be affected by the $\mathrm{CO}$ emulsion or the dentin substrate; b) hybrid layer formed would not be affected by the $\mathrm{CO}$ emulsion or the dentin substrate, or the adhesive system.

\section{METODOLOGIA}

After approval of the research protocol by the university ethics committee (CAAE 35573914.0.0000.5020), 96 sound third human molars were collected from a School of Dentistry Biobank and were randomly divided into 16 groups (6 per group), according to artificial caries or non-caries induction; test-substances: $\mathrm{CO}$ emulsion, $\mathrm{CHX} 2 \%$, calcium hydroxide solution (CHS), and distilled water (DW); and the adhesive systems. Group distributions and samples were performed according to Table 1 . The teeth were examined by stereomicroscope OLYMPUS (20x magnification) to detect enamel defects, cracks, or fractures that might affect the results. Then, they were stored in DW at room temperature until the time of use to prevent dehydration (OLIVEIRA et al., 2010).

The sample size was calculated after a pilot study. Four teeth per group were estimated, considering a power of $80 \%$, a minimal difference between the treatments means of 20.22, a standard deviation of 5.86, and a statistical significance level preset at $5 \%$. To compensate eventual dropouts, six teeth per group were used. 
Table 1 - Group and sample distribution according to healthy or carious substrate, test substance, and adhesive system

\begin{tabular}{ccccccc}
\hline Group & $\begin{array}{c}\text { N } \\
\text { (specimens) }\end{array}$ & Substrate & $\begin{array}{c}\text { Acid } \\
\text { etching }\end{array}$ & Substances & $\begin{array}{c}\text { Adhesive } \\
\text { system }\end{array}$ & $\begin{array}{c}* N \\
\text { sections/group }\end{array}$ \\
\hline G1 & 6 & & Yes & CHX2\% & A & 12 \\
G2 & 6 & & No & CHX2\% & C & 12 \\
G3 & 6 & Yes & CO & A & 12 \\
G4 & 6 & Healthy & No & CO & C & 12 \\
G5 & 6 & & Yes & CHS & A & 12 \\
G6 & 6 & & No & CHS & C & 12 \\
G7 & 6 & Yes & DW & A & 12 \\
G8 & 6 & & No & DW & C & 12 \\
& & & Yes & CHX2\% & A & 12 \\
G9 & 6 & & No & CHX2\% & C & 12 \\
G10 & 6 & & Yes & CO & A & 12 \\
G11 & 6 & No & CO & C & 12 \\
G12 & 6 & Carious & Yes & CHS & A & 12 \\
G13 & 6 & & No & CHS & C & 12 \\
G14 & 6 & & Yes & DW & A & 12 \\
G15 & 6 & & No & DW & C & 12 \\
G16 & 6 & & & & & \\
\hline
\end{tabular}

*Each tooth was sectioned into 2 sections (disks). CHX, chlorhexidine; CO, copaiba oil emulsion; CHS, calcium hydroxide solution; DW, distilled water. A -Adper Single Bond ${ }^{\mathrm{TM}}$; CClearfill SE Bond ${ }^{\mathrm{TM}}$

\section{CO oil-resin and emulsion formulations}

Copaifera multijuga Hayne oil-resin was collected according to the methodology proposed by Araújo et al. (2020) e Barbosa et al. (2013).

The $\mathrm{CO}$ emulsion at $10 \%$ was formulated according to methodology proposed by Bandeira et al. (2016). It was composed of distilled water, CO oleoresin, emulsifier, and preservative agent.

\section{Teeth preparation}

The dental occlusal surface of the specimens were prepared following the criteria adopted by Meira et al. (2020). Half of the teeth $(n=48)$ was maintained sound and the other half $(n=48)$ was submitted an artificial induction of caries process according to the 
protocol by Sanabe; Costa; Hebling (2011).Then the dentin disks were cut in mesiodistal direction, resulting in two halves of the same specimen, for a total of 12 sections per group; one half was used for ESEM analysis of dentin surface $(n=6)$ and the other for ESEM hybrid layer's analysis $(n=6)$.

\section{Surface's treatment with or without acid etching}

The specimens of dentin surface's groups treated with the test-substances CHX2\%, CO emulsion, CHS, and DW were etched with phosphoric acid at 37\% (Conditioner Dental Gel, 3M ESPE, St Paul, MN, USA) for $15 \mathrm{~s}$, washed for $15 \mathrm{~s}$ with DW, and dried with absorbent paper to keep moist. Then, $20 \mu \mathrm{L}$ of each substance was applied on conditioned dentin with a micropipette. The solution was kept passively for $60 \mathrm{~s}$, and the excess was removed with absorbent paper to leave a moist surface (RICCI et al., 2020).

For the CHS preparation, one gram of $\mathrm{Ca}(\mathrm{OH})_{2}$ powder was mixed with $20 \mathrm{~mL}$ of DW. The obtained solution was stored in a refrigerator for $24 \mathrm{~h}$ to decantation, and the supernatant was used.

The specimens that were not acid-etching were treated only with specific substances for each group and analyzed immediately by ESEM.

\section{Adhesive system application}

After the dentin surface treatment, Adper Single Bond $2^{\mathrm{TM}}$ or Clearfil SE Bond ${ }^{\mathrm{TM}}$ was applied following the manufacturer's guidelines (Table 2). 
Table 2 - Adhesives system used in the study

\begin{tabular}{|c|c|c|c|c|}
\hline Material & Manufacturer & Classification & Composition & Application mode \\
\hline $\begin{array}{c}\text { Adper } \\
\text { Single Bond } \\
2^{\mathrm{TM}} \\
\text { LOT no } \\
\text { EE0623 }\end{array}$ & $\begin{array}{c}\text { 3M/ESPE, St } \\
\text { Paul, } \\
\text { MN,USA }\end{array}$ & $\begin{array}{l}\text { Two-step } \\
\text { etch-and- } \\
\text { rinse } \\
\text { adhesive }\end{array}$ & $\begin{array}{c}\text { 37\% phosphoric acid } \\
\text { (DFL, Rio de Janeiro, RJ, } \\
\text { Brazil) } \\
\text { BIS-GMA, HEMA, } \\
\text { dimethacrylate, amines, } \\
\text { methacrylic copolymer of } \\
\text { polyacrylic and } \\
\text { polyitaconic acids, } \\
\text { ethanol, water, } \\
\text { photoinitiator }\end{array}$ & $\begin{array}{l}\text { 1. Apply etchant for } \\
15 \mathrm{~s} \\
\text { 2. Rinse for } 30 \mathrm{~s} \\
\text { 3. Air dry to remove } \\
\text { excess water } \\
\text { 4. Apply } 2 \\
\text { consecutive coats of } \\
\text { adhesive for } 15 \mathrm{~s} \text { with } \\
\text { gentle agitation } \\
\text { 5. Gently air dry for } 5 \mathrm{~s} \\
\text { to evaporate the } \\
\text { solvent } \\
\text { 6. Light-cure for } 10 \mathrm{~s}\end{array}$ \\
\hline $\begin{array}{l}\text { Clearfil SE } \\
\text { Bond } \\
\text { LOT no } \\
\text { Primer: } \\
\text { 4S0251 } \\
\text { Bond: } \\
\text { 5A0405 }\end{array}$ & $\begin{array}{c}\text { Kuraray } \\
\text { Noritake, } \\
\text { Tokyo, Japan }\end{array}$ & $\begin{array}{l}\text { Two-step } \\
\text { self-etching } \\
\text { adhesive }\end{array}$ & $\begin{array}{c}\text { Primer: 10-MDP, } \\
\text { HEMA, hydrophilic } \\
\text { dimethacrylate, di- } \\
\text { camphorquinone, } \\
\text { aromatic tert-amine, } \\
\text { water } \\
\text { Bond: 10-MDP, Bis- } \\
\text { GMA, HEMA, } \\
\text { hydrophilic } \\
\text { dimethacrylate, } \\
\text { photoinitiator, aromatic } \\
\text { tert- amine, silanized } \\
\text { colloidal silica }\end{array}$ & $\begin{array}{l}\text { 1. Apply primer to } \\
\text { enamel and leave in } \\
\text { place for } 20 \mathrm{~s} \\
\text { 2. Blow dry for } 20 \mathrm{~s} \text { at } \\
\text { a distance of } 20 \mathrm{~cm} \\
\text { 3. Apply } 2 \\
\text { consecutive coats of } \\
\text { adhesive for } 20 \mathrm{~s} \\
\text { 4. Gently air dry for } 5 \mathrm{~s} \\
\text { 5. Light-cure for } 10 \mathrm{~s}\end{array}$ \\
\hline
\end{tabular}

Then, four additional layers of bonding agent were applied and light-cured (Radii CAL $1200 \mathrm{~mW} / \mathrm{cm} 2$, SDI, São Paulo, Brazil) with power monitored by radiometer with irradiance between 440 and $480 \mathrm{~mW} / \mathrm{cm}$ for $35 \mathrm{~s}$ (GATEVA; KABAKTCHIEVA, 2012).

Finally, all specimens were stored in DW at 37oC for $24 \mathrm{~h}$ (MEIRA et al., 2020). After, the samples were sectioned in mesiodistal direction using a cutting machine with a diamond disc at high speed (Buehler, model 11- 4253, series 15 LC, Lake Bluff, ILL 6004 , USA) under constant cooling to expose the adhesive interface. The exposed surface was polished using a polishing machine (AROPOL 2V, AROTEC SA Industry and Trade, Cotia, SP, Brazil) with silicon carbide abrasive (Buehler Ltda., Lake Bluff, IL, USA) granulating 1000 and 4000, under constant cooling and speed of $300 \mathrm{rpm}$. Then, sections were cleaned in an ultrasonic tank containing DW for $10 \mathrm{~min}$ to remove any residue of cutting and polishing procedures. The specimens were demineralized with $6 \mathrm{~N} \mathrm{HCl}$ for 30 
s, deproteinized with $2.5 \% \mathrm{NaOCl}$ for $10 \mathrm{~min}$, and washed with DW (GUVEN; AKTOREN, 2015) to be submitted to ESEM hybrid layer analysis.

\section{ESEM}

Morphology of Dentin's Surface

After dentin surface treatments and prior to adhesive use, a specimen of each tooth was analyzed by ESEM QUANTA (Model $250 \mathrm{EIF}$ ) under $25 \mathrm{kV}$ with a secondary electron detector and low vacuum. Micrographs were obtained from the entire length of the treated dentin surface with 2000x magnification and scored according to criteria proposed by Oliveira et al. (2010).

In both ESEM analysis, the micrographs were previously coded and analyzed in duplicate with one-week interval by a blinded investigator, calibrated with ESEM reference images to avoid groups' identification (BANERJEE; KIDD; WATSON, 2000; WANG; YAO, 2010). Four micrographs for each specimen were analyzed.

\section{Statistical analysis}

The Kappa test was used for intra-examiner agreement concerning dentin's surface and hybrid layer's morphology analysis ( 0.84 and 0.86 , respectively). The results for dentin surface and hybrid layer's morphology were submitted to Kruskal-Wallis test at $5 \%$ significance, and the thickness results were submitted to Shapiro-Wilk test or KruskalWallis tests with $5 \%$ significance.

\section{RESULTS}

\section{Dentin Surface}

After acid-etching, the sound and caries-affected dentin surfaces treated with DW presented dentin peritubular exposure, no smear layer, and all dentinal tubules opened. The application of $\mathrm{CHX} 2 \%$ and $\mathrm{CO}$ emulsion on both dentin substrates resulted in a minimal amount of smear layer, and almost all dentinal tubules opened, but only CHX treated dentin surface showed a presence of phosphate crystals precipitates in some areas. The conditioned sound dentin surfaces treated with CHS had practically all dentinal 
tubules obliterated, and that caries-affected showed a higher number of open dentinal tubules (Figure 1).

Figure 1 - Evaluation of ESEM conditioned dentin surface. Sound: DW (A);CHX 2\% (B); CO (C); CHS (D). Caries-affected: DW (E); CHX 2\% (F); CO $(\mathrm{G})$; CHS $(\mathrm{H})$. The arrows point open $(\mathrm{C}, \mathrm{E}, \mathrm{G})$ and obliterated $(\mathrm{D}, \mathrm{H})$ dentinal tubules, and phosphate's salts (B, F). (2,000× magnification)

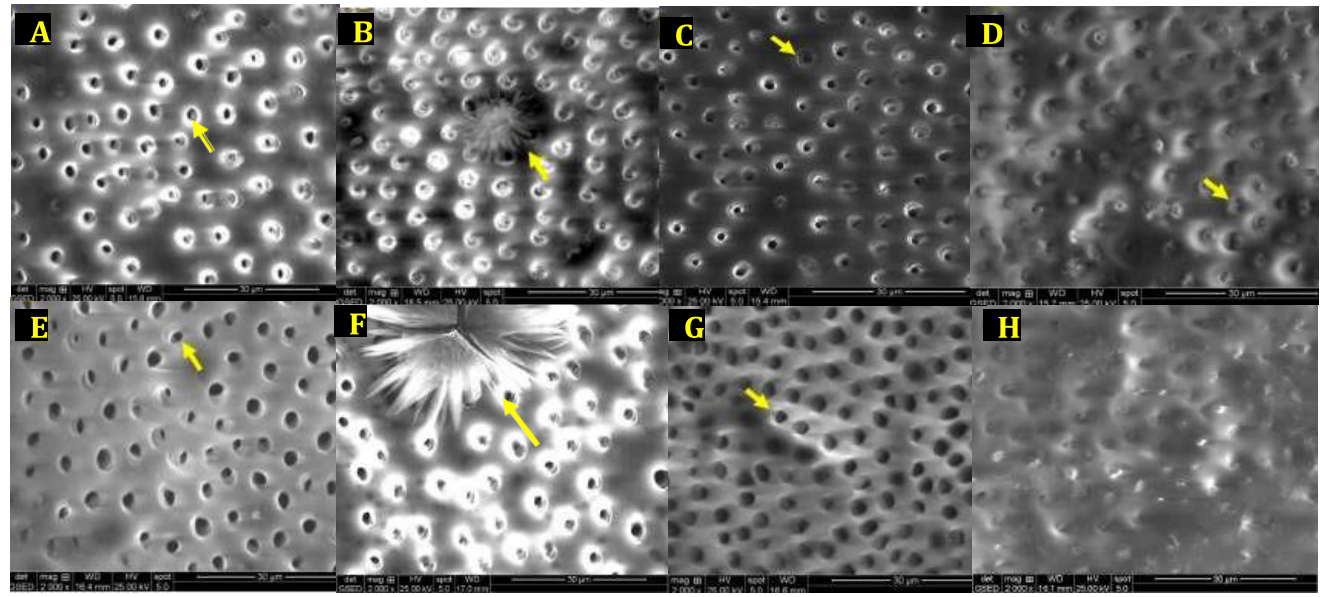

In contrast, the surfaces treated DW, $\mathrm{CHX} 2 \%$, and $\mathrm{CO}$ emulsion without prior acidetching showed a moderate amount of smear layer, and most dentinal tubules were obliterated. The not-etched dentin treated with CHS showed a large amount of smear layer with the formation of precipitates products on the surface and all dentinal tubules obliterated (Figure 2).

Figure 2- ESEM not conditioned dentin surface. Sound: DW (A); CHX 2\% (B); CO (C); CHS (D). Caries-affected: DW (E); CHX 2\%(F); CO (G); CHS (H) .The arrows point obliterated dentinal tubules $(C, G)$, precipitation on dentin surface $(D, H) .(2,000 \times$ magnification $)$

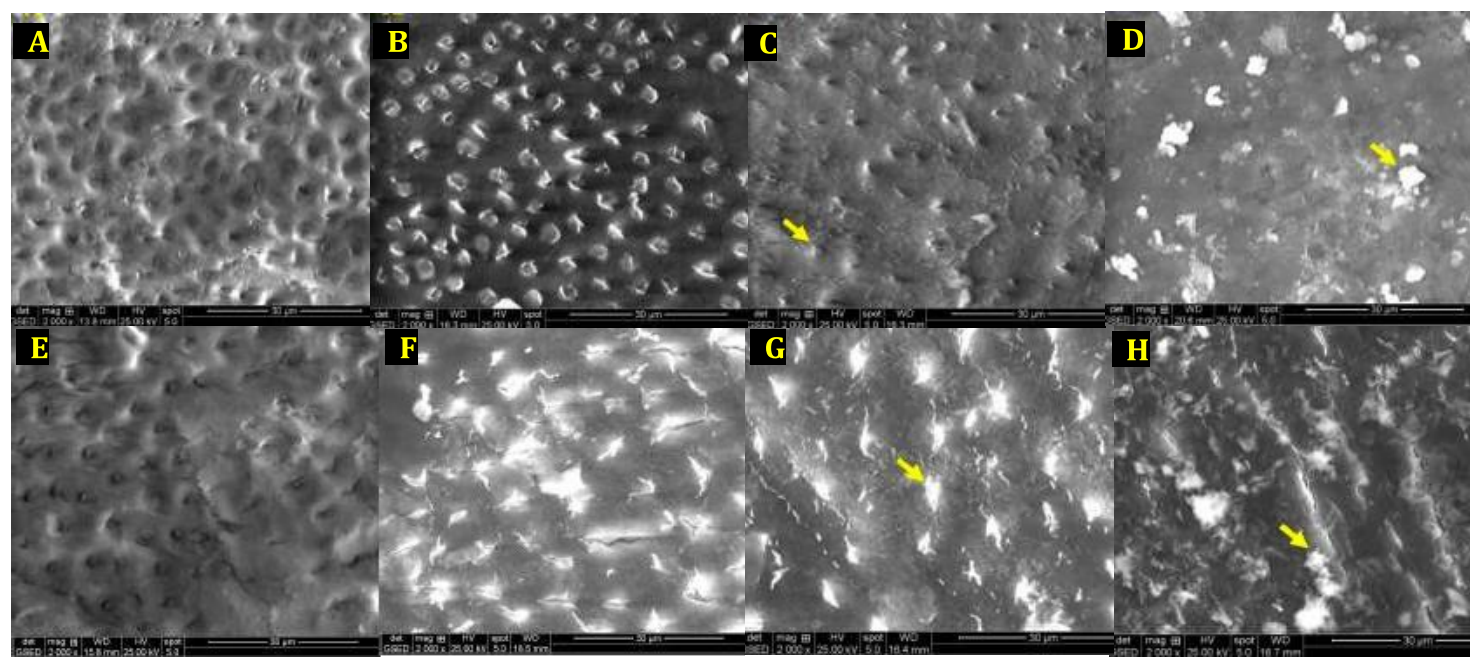


According to test-substance and acid-etching, the scores means from sound and caries-affected dentin surfaces were presented in Table 3. A significant difference ( $p$ $<0.0001)$ in dentin surface morphology was observed at the CHS group on conditioned and not conditioned sound dentin. The $\mathrm{CO}$ emulsion showed a slight score mean increase in caries- affected dentin than compared with the gold-standard dentin cleaning substance $\mathrm{CHX} 2 \%(\mathrm{p}<0.05)$, although it was seen the presence of phosphate crystals precipitates on dentin surface in both dentin substrates when treated with $\mathrm{CHX} 2 \%$.

Table 3- Scores mean of sound and caries-affected dentin treated with test-substances with or without etching.

\begin{tabular}{c|c|cc|cc|cc|cc}
\hline & & \multicolumn{2}{|c|}{ DW } & \multicolumn{2}{|c|}{ CHX 2\% } & \multicolumn{2}{|c|}{ CO emulsion } & \multicolumn{2}{|c}{ CHS } \\
\hline $\begin{array}{c}\text { Scores } \\
0-3\end{array}$ & Dentin & S & CA & S & CA & S & CA & S & CA \\
\hline Mean & $\begin{array}{c}\text { With } \\
\text { acid- } \\
\text { etching* }\end{array}$ & 0.08 & 0 & 0.12 & 0.46 & 0.54 & 0.33 & $1.50^{\text {a }}$ & 0.46 \\
\hline Mean & $\begin{array}{c}\text { Without } \\
\text { acid- } \\
\text { etching** }\end{array}$ & 1.12 & $2.12^{\mathrm{a}}$ & $2.00^{\mathrm{a}}$ & $2.17^{\mathrm{a}}$ & $2.17^{\mathrm{a}}$ & $2.42^{\mathrm{ab}}$ & $2.98^{\mathrm{b}}$ & $2.67^{\mathrm{ab}}$ \\
\hline
\end{tabular}

S - Sound dentin; CA - Caries-affected dentin; S - Sound dentin; CA - Cariesaffected dentin; DW-Distilled Water; CO-Copaíba; CHS -Calcium Hydroxide Solution. (p) Kruskal-Wallis $<0.0001$; *Letter a means statistical difference ( $\mathrm{p}<$ $0.05)$; **Different letters mean statistical difference $(\mathrm{p}<0.05)$.

\section{Hybrid Layer}

\section{Adper Single Bond $2^{\mathrm{TM}}$}

The hybrid layer with on sound and caries-affected dentin treated with DW was presented as thick and uniform with long and numerous resin tags. In the same direction, on both dentin substrates treated with $\mathrm{CHX} 2 \%$ and $\mathrm{CO}$ emulsion, the hybrid layer was presented as thick, regular, and uniform, with long resin tags, but in smaller quantities than on DW group. CHS produces a hybrid layer with a moderate amount of resin tags (Figure 3). 
Figure 3: ESEM Hybrid Layer (HL) with Single Bond 2TM adhesive (A) on dentin (D). Sound: DW(A); CHX 2\%(B); CO (C); CHS (D). Caries-affected DW(E); CHX 2\%(F); CO (G); CHS

$(\mathrm{H})$. The arrows point resin tags. $(1,000 \times$ magnification $)$

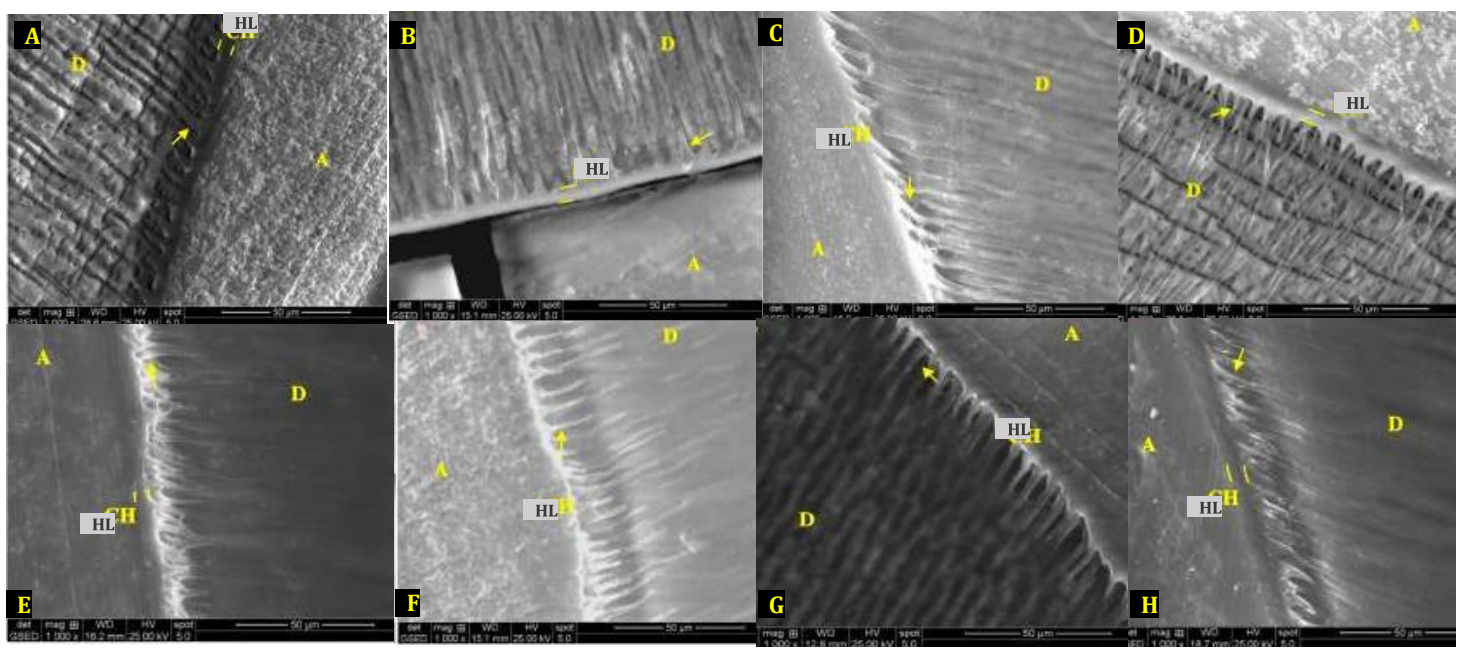

There was no statistical difference between the hybrid layer formed with Adper Single Bond 2TM on sound and caries-affected dentin treated with the test-substances (Table 4), neither in the hybrid layer's thickness formed $(\mathrm{p}<0.05)$ (Table 5).

Table 4- Scores mean of hybrid layer formed with Single Bond $2^{\mathrm{TM}}$ and Clearfil SE BondT ${ }^{\mathrm{M}}$ on sound and caries-affected dentin after treatment with test-substances.

\begin{tabular}{c|c|cc|cc|cc|cc|c}
\hline & & \multicolumn{2}{|c|}{ DW } & \multicolumn{2}{|c|}{ CHX 2\% } & CO emulsion & \multicolumn{2}{|c|}{ CHS } & $\begin{array}{c}\mathrm{p} \\
\text { (Kruskal - } \\
\text { Wallis test) }\end{array}$ \\
\hline $\begin{array}{c}\text { Scores } \\
(1-6)\end{array}$ & $\begin{array}{c}\text { Hybrid } \\
\text { layer }\end{array}$ & S & CA & S & CA & S & CA & S & CA & \\
\hline Mean & $\begin{array}{c}\text { Adper } \\
\text { Single } \\
\text { Bond } \\
2^{\mathrm{TM}}\end{array}$ & $1.00^{\mathrm{a}}$ & $1.00^{\mathrm{a}}$ & $1.05^{\mathrm{a}}$ & $1.30^{\mathrm{a}}$ & $1.05^{\mathrm{a}}$ & $1.10^{\mathrm{a}}$ & $1.16^{\mathrm{a}}$ & $1.60^{\mathrm{a}}$ & 0.012 \\
\hline Mean & $\begin{array}{c}\text { Clearfil } \\
\mathrm{SE} \\
\text { Sond }^{\mathrm{TM}}\end{array}$ \\
\hline
\end{tabular}

S - Sound dentin; CA - Caries-affected dentin; DW-Distilled Water; CO-Copaíba; CHS

-Calcium Hydroxide Solution. *Different letters mean statistical difference between groups $(\mathrm{p}<0.05)$. 
Table 5 - Comparison of the average thickness of the hybrid layer according to the substrate, adhesive system and test substances.

\begin{tabular}{|c|c|c|c|c|}
\hline DENTIN & SUBSTANCE & ADHESIVE & $\begin{array}{c}\text { THICKNESS- } \\
\mu \mathrm{m} \\
\text { MEAN (SD) }\end{array}$ & $\mathrm{N}$ \\
\hline \multirow{4}{*}{ SOUND } & DW & $\begin{array}{l}\text { SINGLE BOND } \\
\text { CLEARFIL SE }{ }^{\mathrm{TM}}\end{array}$ & $\begin{array}{l}4,5(1,17)^{\mathrm{b}} \\
4,7(0,67)^{\mathrm{b}}\end{array}$ & $\begin{array}{l}10 \\
10\end{array}$ \\
\hline & CHX & $\begin{array}{l}\text { SINGLE BOND }{ }^{\mathrm{TM}} \\
\text { CLEARFIL SE }^{\mathrm{TM}}\end{array}$ & $\begin{array}{l}4,0(0,94)^{\mathrm{b}} \\
3,5(1,17)^{\mathrm{b}, \mathrm{c}}\end{array}$ & $\begin{array}{l}10 \\
10\end{array}$ \\
\hline & $\mathrm{CO}$ & $\begin{array}{l}\text { SINGLE BOND }^{\mathrm{TM}} \\
\text { CLEARFIL SE }^{\mathrm{TM}}\end{array}$ & $\begin{array}{l}5,1(0,73)^{\mathrm{b}} \\
2,6(0,84)^{\mathrm{a}}\end{array}$ & $\begin{array}{l}10 \\
10\end{array}$ \\
\hline & CHS & $\begin{array}{l}\text { SINGLE BOND }^{\mathrm{TM}} \\
\text { CLEARFIL SE }^{\mathrm{TM}}\end{array}$ & $\begin{array}{l}3,9(0,56)^{b} \\
3,5(0,52)^{b}\end{array}$ & $\begin{array}{l}10 \\
10\end{array}$ \\
\hline \multirow{4}{*}{$\begin{array}{c}\text { CARIES } \\
\text { AFFECTED }\end{array}$} & DW & $\begin{array}{l}\text { SINGLE BOND } \\
\text { CLEARFIL SE }^{\mathrm{TM}}\end{array}$ & $\begin{array}{l}4,2(0,78)^{\mathrm{b}} \\
3,0(0,47)^{\mathrm{c}}\end{array}$ & $\begin{array}{l}10 \\
10\end{array}$ \\
\hline & CHX & $\begin{array}{l}\text { SINGLE BOND } \\
\text { CLEARFIL SE }^{\mathrm{TM}}\end{array}$ & $\begin{array}{l}3,2(0,63)^{\mathrm{c}} \\
2,7(0,48)^{\mathrm{a}}\end{array}$ & $\begin{array}{l}10 \\
10\end{array}$ \\
\hline & $\mathrm{CO}$ & $\begin{array}{l}\text { SINGLE BOND } \\
\text { CLEARFIL SE }^{\mathrm{TM}}\end{array}$ & $\begin{array}{l}4,0(0,94)^{\mathrm{b}} \\
2,6(0,96)^{\mathrm{a}}\end{array}$ & $\begin{array}{l}10 \\
10\end{array}$ \\
\hline & CHS & $\begin{array}{l}\text { SINGLE BOND } \\
\text { CLEARFIL SE }^{\mathrm{TM}}\end{array}$ & $\begin{array}{c}4,1(0,73)^{\mathrm{b}} \\
*\end{array}$ & $\begin{array}{c}10 \\
3\end{array}$ \\
\hline
\end{tabular}

$\mathrm{DW}=$ distilled water; $\mathrm{CHX}=$ chlorhexidine digluconate; $\mathrm{CO}=$ copaiba emulsion; $\mathrm{CHS}=$ calcium hydroxide solution. Kruskal-Wallis test $\mathrm{H}$ value $=48,1433$, (p) < 0.0001; Different letters mean statistical difference between groups $(\mathrm{p}<0.05)$; Group didn't enter in statistical analysis.

\section{Clearfil SE Bond ${ }^{\mathrm{TM}}$}

Using self-etching adhesive system, on both dentin substrates treated with DW, CHS, and $\mathrm{CHX} 2 \%$, the hybrid layer was presented as regular and uniform, but with irregular resin tags and less infiltration in intratubular dentin. $\mathrm{CO}$ emulsion use as a dentin biomodifying agent also produced a regular and uniform hybrid layer, but with a large number of resin tags (Figure 4). 
Figure 4 - ESEM Hybrid Layer (HL) with Clearfil SE Bond 2TM adhesive (A) on dentin (D). Sound: DW(A); CHX 2\%(B); CO (C); CHS (D). Caries-affected DW(E); CHX 2\%(F); CO (G); CHS $(\mathrm{H})$. The arrows point resin tags. (1,000× magnification)

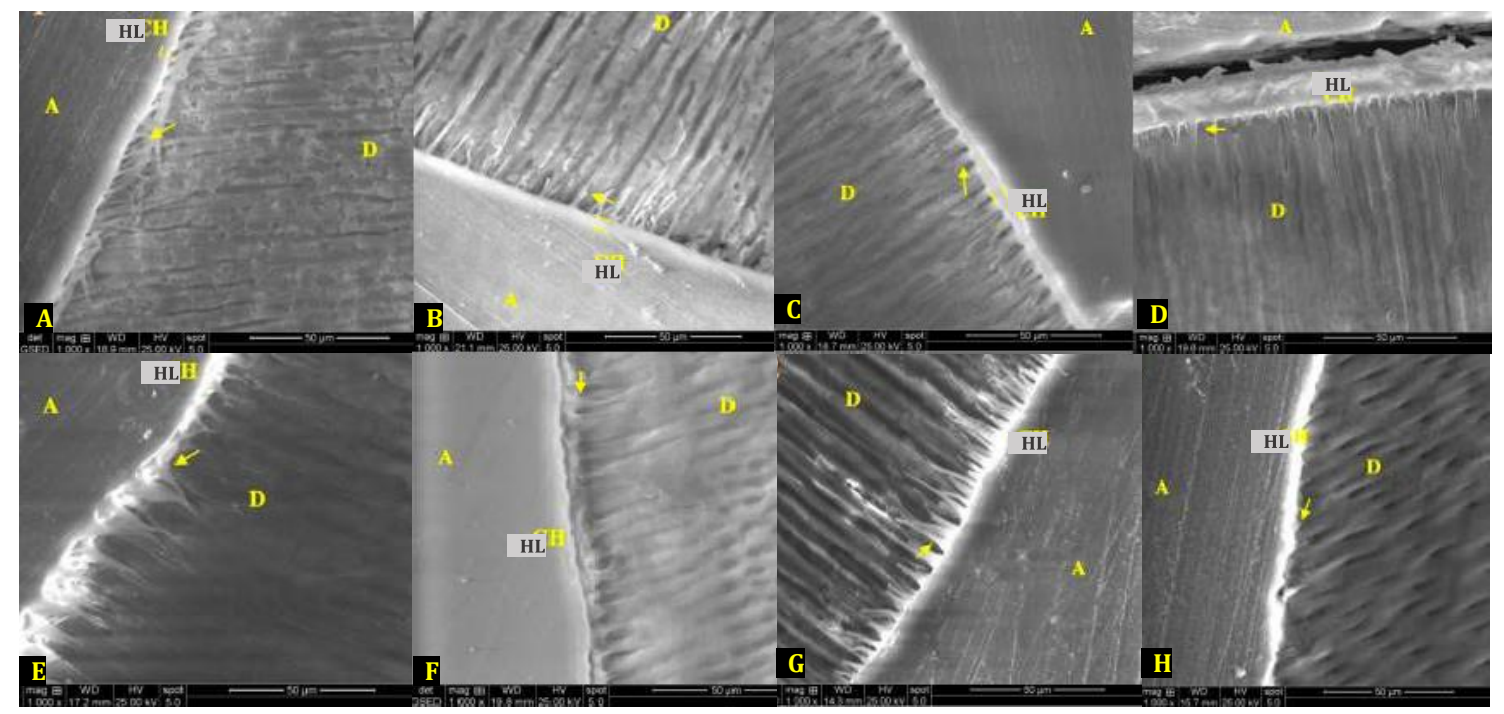

The hybrid layer with Clearfil SE Bond ${ }^{\mathrm{TM}}$ on caries-affected dentin treated with CHS presented statistical difference to the CO emulsion group $(\mathrm{p}<0.05)$. There was no statistical difference in the hybrid layer with this adhesive on sound dentin, regardless of tested substances (Table 4).

The hybrid layer formed on sound and caries-affected dentin treated with $\mathrm{CO}$ emulsion presented the smallest thickness $(2.60 \pm 0.84 \mu \mathrm{m}$ and $2.60 \pm 0.96 \mu \mathrm{m}$, respectively). Comparing the test-substances, substrates, and adhesives systems, there was a statistical difference between the hybrid layer's thickness with Clearfil SE Bond ${ }^{\mathrm{TM}}$ on sound dentin treated with CO emulsion and DW $(\mathrm{p}<0.05)$. There was no statistical difference in caries-affected dentin between DW, CHX 2\%, and $\mathrm{CO}$ emulsion with this adhesive (Table 5).

\section{DISCUSSION}

A microbiological protocol of caries induction was used in this study to simulate the natural process of carious dentin. The microbiological method simulates the caries process using bacterial strains or mixed cultures as acid producers in cultures. It also reproduces some characteristics described for natural dentin caries, such as color and the presence of two distinct layers. Thus, if a study needs to simulate a dentin caries lesion 
with an evident infected layer prior to caries removal, the microbiological method seems more appropriate. Furthermore, the microbiological method provides a morphological pattern of collagen degradation, a formation of an infected dentin layer, an extensive demineralization of intertubular dentin, and a discreet opening of dentinal tubules that more closely resembles natural lesions (MARQUEZAN et al., 2009).

The caries dentin surfaces had the infected dentin removed with hand tools, leaving only caries affected dentin, simulating a clinical situation. This instrument was used to ensure the operator greater control in removing decayed tissue, giving a conservative preparation. Moreover, a research (LI et al., 2011) shows a minor amount of smear layer and higher number of open dentinal tubules in surface prepared by the chemical-mechanical method, compared with rotatory instruments.

The current investigation has demonstrated that $\mathrm{CO}$ emulsion did not interfere on the dentin surface morphology, independent of the substrate and the adhesive system since the use of the emulsion resulted in a surface without morphology variations, presenting no physical barriers to adhesive penetration, unlike the dentin surface treated with $\mathrm{CHX} 2 \%$, in which case, phosphate salts were found in both dentin substrates (sound and carious); consequently the first null hypothesis was not rejected. Moreover, CO emulsion interfered positively in the hybrid layer of the sound and the carious dentin groups, producing a homogenous, regular layer with a great monomer infiltration in dentin, regardless of the adhesive system; consequently, the second null hypothesis was rejected.

The treatment of dentin surfaces before application of the adhesive system has a significant influence on adhesion. Some studies have demonstrated the action of CHX $2 \%$ on organic components of the dentin when used as a therapeutic agent after acidetching, improving the quality and increasing the longevity of the adhesive interface (BRESCHI et al., 2010; FRANCISCONI-DOS-RIOS et al., 2015). According to Singh et al. (2011), the use of CHX $0.2 \%$ promotes increased binding of partially demineralized dentin than mineralized one. A recent study10 showed that dentin cavities treated with emulsions based on CO 10\% emulsion presented lower marginal infiltration than CHX $2 \%$ pointing out that this emulsion had a positive effect on marginal adaptation and dentin bond strength. 
In this study, the treatment of conditioned and not-etched dentin surface with CHX $2 \%$ showed phosphate salts' formation, which was seen in a small amount on etched dentin and embedded in smear layer on not-etched one. These phosphate salts are visible on the hydroxyapatite in the form of needle-shaped crystals (NERI et al., 2011). These embedded phosphates seem to have low hydrolytic stability, with non-stable chemical interaction with the exposed collagen, thereby weakening the interfacial integrity, especially in a long-term (GIANNINI et al., 2015).

The results regarding the use of $\mathrm{Ca}(\mathrm{OH})_{2}$ confirmed its recommendation in deep cavities and pulp exposure cases (AL-SABRI et al., 2019). In this study, the application of CHS on the not-conditioned dentin resulted in the formation of precipitates on the surface, increasing the smear layer's irregularity. And even after conditioning with $37 \%$ phosphoric acid, CHS obliterated dentinal tubules, suggesting its contraindication in shallow cavities.

Compared to $\mathrm{CHX} 2 \%$, the application of $\mathrm{CO}$ emulsion as a dentin biomodifier has other biological properties that can aid the pulp tissue response and showed no apparent interference in the hybrid layer, especially with the self-etching adhesive (PIERI et al., 2012; ARAÚJO et al., 2020; BANDEIRA et al., 2020).

The hybrid layer in caries-affected dentin showed irregular and insufficient penetration of resin tags due to the great depth of demineralization by increased acidetching susceptibility. Some authors have also reported a more significant gap between the depth of demineralization, monomers infiltration, and extensive collagen exposed area based on the hybrid layer in caries- affected dentin compared with sound dentin (XUAN; HOU; LÜ, 2010).

A thick hybrid layer formed with conventional adhesive, low effectiveness and adhesive strength is related to the carious process's substrate (DE ALMEIDA NEVES, 2011). Moura; Santos; Ballester (2006) reported variations on the morphological characteristics of the adhesive interface according to the adhesive used, noticing that the hybrid layer formed with self-etching adhesive (Clearfil SE Bond ${ }^{\mathrm{TM}}$ ) presented a thinner hybrid layer and a smaller amount of resin tags in comparison with etch- and-rinse 
adhesive (Adper Single Bond $2^{\mathrm{TM}}$ ). The same result was found in this study, showing a statistical difference in the $\mathrm{CO}$ emulsion group on sound and caries-affected dentin. Besides, previous research (BANDEIRA et al., 2020) showed that both healthy and carious dentin with the Clearfil SE Bond ${ }^{\mathrm{TM}}$ adhesive system presented the lowest bond strength values for all dentin cleaning substances because of the penetrating power of the self-etch adhesive system (Clearfil SE Bond ${ }^{\mathrm{TM}}$ ) in the dentinal tubules and the intertubular dentin was lower than that of the etch-and-rinse adhesive (Adper Single Bond $^{\mathrm{TM}}$ ). Another researches (MOURA; SANTOS; BALLESTER, 2006; DE ALMEIDA NEVES, 2011) showed that hybrid layers created by the etch- and-rinse adhesives were thicker than those observed in the specimens bonded with the self- etching adhesive system, and high immediate bond strength has been reported for these self- etching systems, suggesting the absence of correlation between hybrid layer thickness and bonding efficacy. Our results was in agreement with the observations of many studies which prove that etch and rinse adhesives produce a thicker hybrid layer with funnelshaped resin tags due to phosphoric acid etching ( $\mathrm{pH}-0.1)$ while the self-etching adhesives showed a continuous and thinner hybrid layer with cylindrical resin tags due to mild $\mathrm{pH}$ (PASHLEY et al., 2004; MOURA; SANTOS; BALLESTER, 2006; ALBALADEJO et al., 2010).

Wang; Spencer; Walker (2007) observed the irregular penetration of resin tags in caries-affected dentin and reported that the carious process could cause dentin's irregular demineralization due to mineral loss in some areas and mineral precipitation in the dentinal tubules in other regions, similar to our results.

In this study, in sound and caries-affected dentin, $\mathrm{CO}$ emulsion offers promising results as an alternative to improve the hybrid layer's quality and leave it homogeneous, regular, and with a large number of resin tags when used with conventional and selfetching adhesives.

Pashley et al. (2004) and Sanabe; Costa; Hebling (2011) indicated mineral oil as a solution for specimen storage to preserve adhesive interface and reduce hydrolytic and enzymatic collagen degradation, considering that the collagenolytic activity does not happen in the absence of water. As the $\mathrm{CO}$ emulsion is hydrophobic, its use as a dentin 
biomodifier has antibacterial activity and MMP-inhibiting properties and may maintain hybrid layer stability. It can be attributed to its action of preventing enzymatic hydrolysis of collagen due to its oily nature, similar to that of mineral oil. This may have contributed to its positive effect on marginal adaptation (BANDEIRA et al., 2018).

In addition to its hydrophobic and antimicrobial characteristics (PIERI et al., 2012; BANDEIRA et al., 2018), the CO oleoresin also has anti-inflammatory activity (ARAÚJO et al., 2020), biocompatibility (BANDEIRA et al., 2018; BANDEIRA et al., 2020), and activity against Streptococcus mutans reducing the incidence of recurrent caries (PIERI et al., 2012; BANDEIRA et al., 2018).

The thickness average of the hybrid layer with Adper Single Bond $2^{\mathrm{TM}}$ found in this study was similar to those reported in the literature (SKUPIEN et al., 2010; ROSA;SILVA;TOSTES, 2015), different from the groups with the Clearfil SE Bond ${ }^{\mathrm{TM}}$ adhesive that presented a higher hybrid layer thickness (SKUPIEN et al., 2010), which is possibly related to the variability of the methodologies used, mainly concerning the number of adhesive layers applied. It is suggested that the hybrid layer's homogeneity with a regular formation of resin tags, where monomers leak entirely and fill the collagen matrix, is more important than its thickness since this fact can allow the identification of a high-quality hybrid layer and the success of bonding forces (HORI; CARVALHO, 2012).

The ESEM used in this research has become the most popular tool to morphologically analyze dentin surfaces and adhesive interfaces because it allowed the specimens to be examined in their natural state, hydrated, and without sample preparation. Also, a few ESEM studies indicating the effective thickness of hybrid layer have been published. According to Pereira et al. (2014), the samples' analysis in a high vacuum favors a greater formation of defects and gaps than to the analysis under a low vacuum.

A limitation of this analysis was the lack of scientific evidence in the literature on copaiba-based emulsions' clinical use, making a comparison with other studies difficult. However, the incorporation of $\mathrm{CO}$ emulsion as a dentin biomodifier represents a gain in the dental restorative process due to its biological properties. 


\section{CONCLUSION}

The application of $\mathrm{CO}$ emulsion as a dentin biomodifier possibly did not interfere on the sound and caries-affected dentin surfaces' natural morphology, presented a regular and uniform hybrid layer, and exhibited significant monomeric infiltration, regardless of the adhesive system used. Considering it and its biological properties, the use of CO emulsion as dentin biomodifier before the etch-and-rinse and self-etching adhesives shows to be a promise in dentistry.

\section{REFERENCES}

ALBALADEJO, A.; OSORIO, R.; TOLEDANO, M.; FERRARI. M. Hybrid layers of etch-and-rinse versus self-etching adhesive systems. Med Oral Patol Oral Cir Bucal, v.15, n.1, p.e112-8, 2010. 10.4317/medoral.15.e112

AL-SABRI, F.A.; EL-MARAKBY, A.M.; ABDULRAB, S.; AL-SHAMIRI, H.M.; ALMANSOUB, T. Effect of calcium hydroxide on deep caries dentin: a clinical study. $\mathbf{J}$

Clin Res Dent, v.2, n.1, p.1-4, 2019.

ARAÚJO, L.C.R.; LINS, M.A.; LIMA, G.R.; MORESCHI, A.R.C.; LIMA, E.S.; HANAN, S.A.; TODA. C.; BANDEIRA. M.F.C.L. Atividade do óleo de copaíba sobre radicais livres formados durante a resposta inflamatória. Braz J of Develop, v.6, n.7, p. 53538-553, 2020. http://dx.doi.org/10.34117/bjdv6n7-845

BANDEIRA, M.F.; CONDE, N.C.; TODA, C.; CASAROTO, A.R.; LIMA, G.; VASCONCELLOS M.; SOUSA, L.B.; SILVA, L.C.; LUNGAREZE, S.; MEIRA, J. Biopharmaceutical products and biomaterials of the Amazon region used in dentistry. Londres:Intechopen, 2018. doi.org/105772/intechopen.820

BANDEIRA, M.F.; LIMA, G.R.; LOPES, P.P.; TODA, C.; VENÂNCIO, G.N.; LIMA, G.A; VASCONCELLOS, M.C.; MARTINS, L.M.; SAMPAIO, F.C.; CONDE, N.C.O. Dentin cleaning ability of an amazon bioactive: evaluation by scanning electron microscopy. Open Dent J, v.10, n.1, p.182-7, 2016. https://doi.org/10.2174/1874210601610010182.

BANDEIRA, M.F.C.L.; FREITAS, A.L.; MENEZES, M.S.C.; SILVA, J.S.; SOMBRA, G.A.D.; ARAÚJO, E.A.M. Adhesive resistance of a copaiba oil-based dentin biomodifier. Braz Oral Res, v.34, p.e001, 2020. https://doi.org/10.1590/1807-3107bor2020.vol34.0001.

BANERJEE, A.; KIDD, E.A.M.; WATSON, T.F. Scanning electron microscopic observations of human dentine after mechanical caries excavation. J Dent, v.28, n.3, p.179-86, 2000. 10.1016/s0300-5712(99)00064-0

BARBOSA, P.C.S.; WIEDEMANN, L.S.M.; MEDEIROS, R.S.; SAMPAIO, P.T.B.; VIEIRA, G.; VEIGA-JUNIOR, V.F. Phytochemical fingerprints of copaiba oils (Copaifera multijuga Hayne) determined by multivariate analysis. Chem Biodivers, v.10, n.7, p.1350-60, 2013.10.1002/cbdv.201200356 
BRESCHI, L.; MAZZONI, A.; NATO, F.; CARRILHO, M.; VISINTINI, E.; TJÄDERHANE, L.; RUGGERI JR, A.; TAY, F.R.; DORIGO, E.D.S.; PASHLEY, D.H. Chlorhexidine stabilizes the adhesive interface: a 2-year in vitro study. Dent Mater, v.26, n.4, p.320-5, 2010. http://dx.doi.org/10.1016/j. dental.2009.11.153

DE ALMEIDA NEVES, A.; COUTINHO, E.; CARDOSO, M.V.; LAMBRECHTS, P.; VAN MEERBEEK, B. Current concepts and techniques for caries excavation and adhesion to residual dentin. J Adhes Dent, v.13, n.1, p.7-22, 2011. 10.3290/j.jad.a18443

FRANCISCONI-DOS-RIOS， L.F.; CALABRIA, M.P.; CASAS-APAYCO, L.C.; HONÓRIO, H,M.; CARRILHO, M.R.; PEREIRA, J.C.; WANG, L. Chlorhexidine does not improve but preserves bond strength to eroded dentin. Am J Dent, v.28, n.1, p.28-32, 2015.

GARRIDO, A.D.; LIA, R.C.; FRANÇA, S.C.; DA SILVA, J.F.; ASTOLFI-FILHO, S.; SOUSA-NETO. M.D. Laboratory evaluation of the physicochemical properties of a new root canal sealer based on Copaifera multijuga oil-resin. Int Endod J, v.43, n.4, p.28391, 2010. http://dx.doi.org/10.1111/j.1365- 2591.2009.01678.x

GATEVA, N.; KABAKTCHIEVA, R. Hybrid layer thickness in primary and permanent teeth - a comparison between total etch adhesives. J of IMAB, v.18, n.2, p.191-9, 2012. 10.5272/jimab.2012182.191

GIANNINI, M.; MAKISHI, P.; AYRES, A.P.A.; VERMELHO, P.M.; FRONZA, B.M.; NIKAIDO, T.; TAGAMI, J. Self- etch adhesive systems: a literature review. Braz Dent J, v.26, n.1, p.3-10, 2015. https://doi.org/10.1590/0103-6440201302442

GUVEN, Y.; AKTOREN, O. Shear bond strength and ultrastructural interface analysis of different adhesive systems to Er:YAG laser-prepared dentin. Lasers Med Sci, v.30, n.2, p. 769-78, 2015. 10.1007/s10103-013-1424-0

HORI, F.S.; CARVALHO, R.C.R. Experimental adhesives with different hydrophilicity: microshear test in after 1, 7, and 90 days' storage. J Adhes Dent, v.14, n.2, p.107-11, 2012. $\underline{10.3290 / \text { j.jad.a23180 }}$

LAFUENTE, D. SEM analysis of hybrid layer and bonding interface after chlorhexidine use. Oper Dent, v.37, n.2, p.172-80, 2012. http://dx.doi.org/10.2341/10-251-L

LI, H.; WANG, W.M.; YU, S.L.; WEN, Q. Morphological and microtensile bond strength evaluation of three adhesive systems to caries-affected human dentine with chemomechanical caries removal. J Dent, v. 39, n.4, p.332-9, 2011. 10.1016/j.jdent.2011.02.004

MARQUEZAN, M.; CORREAA, F.N.; SANABE, M.E.; RODRIGUES FILHO, L.E.; HEBLING, J.; GUEDES-PINTO, A.C.; MENDES, F.M. Artificial methods of dentine caries induction: A hardness and morphological comparative study. Arch Oral Biol, v.54, n.12, p.1111-17, 2009. 10.1016/j.archoralbio.2009.09.007

MEIRA, J.F.; LIMA, G.R.; LIBÓRIO-KIMURA, T.N.; VASCONCELLOS, M.C.; SAMPAIO, F.C.; TODA, C.; CONDE, N.C.O.; BANDEIRA, M.F.L. Avaliação histomorfométrica do efeito de um biomodificador de dentina à base de óleo de copaiba 
(Copaifera multijuga Hayne) na camada híbrida. Braz J of Develop, v.6, n.9, p.6544558, 2020. 10.34117/bjdv6n9-104

MOURA, S.K.; SANTOS, J.F.F.; BALLESTER, R.Y. Morphological characterization of the tooth/adhesive interface. Braz Dent J, v.17, n.3, p.179-85, 2006. 10.3290/j.jad.a18443

NAKABAYASHI, N.The hibrid layer: A resin-dentin composite. Proc Finn Dent Soc, v.88, n.11, p.321-9,1992.

NERI, V.F.; PASSOS, F.B.A.; VIANA, L.K.A.; RODRIGUES, V.P.A.; SABOIA, S.L. Efficacy of smear layer removal by cavity cleaning solutions: an atomic force microscopy study. Rev Odonto Ciênc, v.26, n.3, p.253-7, 2011. https://doi.org/10.1590/S198065232011000300011

OLIVEIRA, A.C.; LIMA, L.M.; PIZZOLITTO, A.C.; SANTOS-PINTO, L. Evaluation of the smear layer and hybrid layer in noncarious and carious dentin prepared by air abrasion system and diamond tips. Microsc Res Tech, v.73, n.6, p.597-605, 2010. http://dx.doi.org/10.1002/jemt.20798

OZER,F.; BLATZ, M.B. Self-etch and etch-and-rinse adhesive systems in clinical dentistry. Compend Contin Educ Dent, v.34, n.1, p.12-4, 2013.

PASHLEY, D.H.; TAY, F.R.; YIU, C.; HASHIMOTO, M.; BRESCHI, L.; CARVALHO, R.M.; ITO, S. Collagen degradation by host-derived enzymes during aging. J Dent Res, v.83, n.3, p.216-21, 2004.10.1177/154405910408300306

PEREIRA, C.N.B.; DALEPRANE, B.; BARBOSA, P.F.; MOREIRA, A.N.; MAGALHÃES, C.S. Qualitative evaluation of scanning electron microscopy methods in a study of the resin cement/dentine adhesive interface. Microsc Microanal, v.20, n.1, p.268-75, 2014. 10.1017/S143192761301369X

PIERI, F.A.; MUSSI, M.C.; FIORINI, J.E.; MOREIRA, M.A.; SCHNEEDORF, J.M. Bacteriostatic effect of copaiba oil (Copaifera officinalis) against Streptococcus mutans. Braz Dent J, v.23, n.1, p.36-8, 2012. http://dx.doi.org/10.1590/s0103$\underline{64402012000100006}$

RICCI, H.A.; SCHEFFEL, D.L.A.; BALDAN, L.G.; DOS SANTOS, F.J.; JAFELICCI JR, M.; HEBLING. J. Influência da clorexidina na capacidade de umectabilidade da dentina hígida e afetada por cárie por um sistema adesivo. ROBRAC, v.20, n.53, p.11924,2011 .

ROSA, A.J.; SILVA, E.M.; TOSTES, M.A. Scanning electron microscopy analysis of microstructure of the adhesive interface between resin and dentin treated with papain gel. Indian J Dent Res, v.26, n.1, p.77-81, 2015. 10.4103/0970-9290.156816

SAFFARPOUR, A.; SAFFARPOUR, A.; KHARAZIFARD, M.J.; RAD, A.E. Effect of chlorhexidine application protocol on durability of marginal seal of class V restorations. J Dent (Tehran), v.13, n.4, p.231-7, 2016.

SANABE, M.E.; COSTA, C.A.S.; HEBLING, J. Exposed collagen in aged resin-dentin bonds produced on sound and caries-affected dentin in the presence of chlorhexidine. $\mathbf{J}$ Adhes Dent, v.13, n.2, p.117-24, 2011. 10.3290/j.jad.a19239

SINGH, H.; KAPOOR, P.; MESHRAM, G.K.; WARHADPANDE, M.M. Evaluation of substantivity of chlorhexidine to human dentin and its application in adhesive dentistry an in vitro analysis. Indian J Dent, v.2, n.2, p.8-10, 2011. https://doi.org/10.1016/S0975- 


\section{X(11)60003-8}

SKUPIEN, J.A.; SUSIN, A.H.; ANGST, P.D.; ANESI, R.; MACHADO, P.; BORTOLOTTO, T.; KREJCI, I. Micromorphological effects and the thickness of the hybrid layer - a comparison of current adhesive systems. J Adhes Dent, v.12, n.6, p.43542, 2010. http://dx.doi.org/10.3290/j.jad.a18242

XUAN, W.; HOU, B.X.; LÜ, Y.L. Bond strength of different adhesives to normal and caries- affected dentins. Chin Med J, v.123, n.3, p.332-6, 2010.

WANG, Y; SPENCER, P.; WALKER, M.P. Chemical profile of adhesive/caries-affected dentin interfaces using Raman microspectroscopy. J Biomed Mater Res A, v.81, n.2, p.279-86, 2007.10.1002/jbm.a.30981

WANG, Y; YAO, X . Morphological/chemical imaging of demineralized dentin layer in its natural, wet state. Dent Mat, v.26, n.5, p.433-42, 2010. 10.1016/j.dental.2010.01.002

\section{Recebido em: 15/09/2021}

Aprovado em: 30/09/2021

Publicado em: 08/10/2021 